\title{
PERKEMBANGAN INDUSTRI PERBANKAN SYARIAH DI INDONESIA : ANALISIS PELUANG DAN TANTANGAN
}

\author{
Hani Werdi Apriyanti \\ Fakultas Ekonomi UNISSULA, hani.apriyanti@unissula.ac.id
}

\begin{abstract}
ABSTRAK
Industri Perbankan Syariah memiliki peran yang strategis dalam pembangunan ekonomi rakyat, berkontribusi dalam melakukan transformasi perekonomian pada aktivitas ekonomi produktif, bernilai tambah dan inklusif. Akan tetapi di era financial digital dan tingginya persaingan industri jasa keuangan seperti sekarang ini, perbankan syariah menghadapi berbagai tantangan, terutama berkaitan dengan rendahnya Teknologi Informasi dan Komunikasi (ICT) dan keterbatasan modal. Oleh karena itu industri perbankan syariah harus memanfaatkan berbagai peluang ,yaitu dengan menyediakan inovasi produk berbasis Teknologi Informasi dan Komunikasi (ICT) untuk menyediakan beragam pilihan dan memperluas jangkauan pada masyarakat. Akan tetapi, sampai saat ini ivovasi produk perbankan syariah tersebut masih sangat terbatas. Selain itu, hal lain yang tidak kalah penting untuk mendukung perkembangan Perbankan Syariah di Indonesia adalah dengan memanfaatkan peluang pertumbuhan ekonomi, dan meningkatkan ketersediaan dana bank syariah. Dengan memanfaatkan peluang tersebut, industri Perbankan syariah di Indonesia dapat berkembang dan memiliki daya saing.
\end{abstract}

Kata Kunci : Inovasi Produk keuangan, Perbankan Syariah, ICT, pertumbuhan ekonomi 


\section{Pendahuluan}

Perkembangan pasar keuangan syariah di Indonesia selama beberapa tahun terakhir cukup pesat, walaupun pasar keuangan syariah merupakan elemen baru di Indonesia (Alamsyah, 2010). Perkembangan ini ditandai dengan semakin banyaknya lembaga keuangan syariah di Indonesia, seperti perbankan syariah, asuransi syariah, reksadana syariah, dan lembaga keuangan syariah lainya. Perkembangan yang cukup pesat dalam pasar keuangan syariah yang berdampak besar terhadap ekonomi masyarakat, adalah industri perbankan syariah. Industri Perbankan syariah dapat memberikan kontribusi dalam melakukan transformasi perekonomian pada aktivitas ekonomi produktif, bernilai tambah dan inklusif.

Peran strategis industri perbankan syariah dalam pembangunan ekonomi rakyat harus terus ditingkatkan dengan menangkap berbagai peluang yang ada di era financial digital yang ditandai dengan pemanfaatan teknologi dalam produk perbankan. Persaingan ini semakin diperkuat dengan berlakunya Masyarakat Ekonomi Asean (MEA) pada tahun 2016 untuk industri perbankan. Hal ini menjadi peluang sekaligus tantangan bagi industri perbankan syariah di Indonesia. Terlebih sebagai elemen baru, market share industri perbankan syariah di Indonesia masih rendah jika dibandingkan dengan negara tetangga, seperti malaysia. Selain itu jika dilihat dari total aset secara keseluruhan terhadap industri perbankan keseluruhan, total aset perbankan syariah masih berada di kisaran angka $5 \%$. Aset perbankan syariah pada tahun 2016 berada pada peringkat yang jauh jika dibandingkan dengan negara tetangga.

Oleh karena itu, Industri Perbankan syariah harus terus memperkuat diri agar dapat meningkatkan peran dalam mengembangkan perekonomian di Indonesia. Industri perbankan syariah

harus menjadi industri yang kuat, memiliki market share yang tinggi, dan menjadi pilihan masyarakat. Industri perbankan syariah yang merupakan bentuk dari kesadaran masyarakat muslim akan penerapan konsep syariah dalam bidang ekonomi seharusnya mampu menjadi pemain utama dalam industri perbankan, mengingat sebagian besar penduduk di Indonesia adalah muslim.

Industri perbankan syariah harus memanfaatkan berbagai peluang, yaitu dengan menyediakan inovasi produk berbasis Teknologi Informasi dan Komunikasi (ICT) untuk menyediakan beragam pilihan dan memperluas jangkauan pada masyarakat. Selain itu, hal lain yang tidak kalah penting untuk mendukung perkembangan industri perbankan Syariah di Indonesia adalah dengan memanfaatkan peluang pertumbuhan ekonomi, dan meningkatkan ketersediaan dana pada perbankan syariah. Dengan memanfaatkan peluang tersebut, industri Perbankan syariah di Indonesia dapat berkembang dan memiliki daya saing dengan negara-negara tetangga seperti malaysia,dan negara muslim lainya.

Artikel ini merupakan penelitian kualitatif deskriptif yang berusaha menganalisis berbagai tantangan bagi industri perbankan syariah di Indonesia dan peluang yang dapat dimanfaatkan oleh perbankan syariah di Indonesia. Pemanfaatan ICT dalam pengembangan inovasi produk perbankan syariah dan pemenuhan ketersediaan pendanaan bagi perbankan syariah akan membantu Industri perbankan syariah dalam menguatkan posisi tawar, dan menjadi industri perbankan yang kuat dan berkontribusi bagi perekonomian Indonesia .

\section{Tinjauan Pustaka}

\section{Perbankan Syariah}

Perbankan syariah adalah segala sesuatu yang menyangkut tentang bank syariah dan unit usaha syariah, mencakup kelembagaan kegiatan usaha, serta cara dan proses dalam melaksanakan kegiatan usahanya (Undang-undang No 21 Tahun 2008). Bank syariah adalah Bank yang menjalankan kegiatan usahanya berdasarkan prinsip syariah. Prinsip Syariah adalah prinsip hukum islam dalam kegiatan Perbankan berdasarkan fatwa yang dilkeluarkan oleh lembaga yang memiliki kewenangan dalam penetapan fatwa di bidang syariah (Booklet Perbankan Indonesia 2016). Industri perbankan syariah memiliki karakteristik umum yang melekat pada industri perbankan, yaitu industri yang padat regulasi, dan industri yang berdasarkan pada kepercayaan. Sistem perbankan syariah di Inonesia dilaksanakan dengan sistem prinsip bagi hasil, mengedepankan nilai kebersamaan, ukhuwah, dan penghindaran unsur spekulatif dalam setiap transaksinya (Alamsyah, 2010).

\section{Perkembangan Industri Perbankan Syariah di Indonesia}

Industri perbankan syariah di Indonesia mengalamai pertumbuhan yang bervariasi sesuai dengan pertumbuhan ekonomi nasional. Pengembangan industri perbankan syariah di Indonesia dilandasi oleh Undang-Undang (UU) yang dikeluarkan oleh Pemerintah, maupun kebijakan-kebijakan yang dikeluarkan oleh 
otoritas perbankan. Salah satu UU yang melandasi awal perkembangan Perbankan syariah adalah Undang-Undang No.21 Tahun 2008 tentang Perbankan Syariah yang terbit tanggal 16 Juli 2008. Dengan Undang-Undang tersebut, maka pengembangan industri perbankan syariah nasional memiliki landasan hukum yang cukup kuat, sehingga mendorong pertumbuhan industri ini lebih cepat. Percepatan Pertumbuhan perbankan syariah di Indonesia, sampai saat ini terus didorong oleh otoritas perbankan, yaitu Otoritas Jasa keuangan menuju industri perbankan syariah yang sehat, berkelanjutan, dan berkontribusi positif dalam mendukung pembangunan ekonomi yang berkualitas.

Dengan progres perkembangannya yang impresif, yang mencapai rata-rata pertumbuhan aset lebih dari $65 \%$ pertahun dalam lima tahun terakhir, peran industri perbankan syariah dalam mendukung perekonomian nasional semakin signifikan. Peran strategis ini terus didorong dengan beberapa kebijakan yang telah ditetapan oleh lembaga yang berwenang. Hal ini terbukti bahwa salah satu prioritas kebijakan OJK pada tahun 2016 sektor perbankan, adalah peningkatan pilar utama dalam pengembangan perbankan syariah. Upaya ini dapat menjadikan perbankan syariah sebagai alternatif sistem perbankan yang kredibel dan dapat dinimati oleh seluruh golongan masyarakat Indonesia tanpa terkecuali. Inovasi produk yang sejalan dengan pemenuhan kebutuhan masyarakat dapat melahirkan produk kontribusi perbankan syariah (Booklet Perbankan Indonesia 2016).

\section{Inovasi Produk Perbankan Syariah}

Dalam menjalankan kegiatan usahanya, perbankan syariah berlandaskan pada prinsip bagi hasil. Karakteristik yang ada dalam produk perbankan syariah ini, memberikan alternatif sistem perbankan yang saling menguntungkan bagi kedua belah pihak, yaitu masyarakat dan perbankan, serta mengedepankan aspek keadilan dalam bertransaksi, investasi yang beretika, nilainilai kebersamaan dan ukhuwah dalam berproduksi, dan menghindari kegiatan spekulatif dalam bertransaksi (Henni, 2011).

Produk perbankan syariah, saat ini terus dikembangkan, yaitu dengan menyediakan beragam produk serta layanan jasa perbankan yang beragam dengan skema keuangan yang lebih bervariatif. Upaya ini merupakan upaya yang disebut sebagai inovasi dalam produk perbankan syariah. Inovasi produk perbankan syariah ini merupakan

bank yang variatif (Henni, 2011). Inovasi produk yang dilakukan perbankan syariah dapat berupa produk yang akan dikemas kembali (repackage) maupun produk baru. (new product). Beberapa inovasi produk yang telah dilakukan oleh Perbankan syariah di Indonesia disajikan dalam tabel 1.

Tabel 1. Inovasi Produk yang telah dilakukan oleh Perbankan Syariah di Indonesia

\begin{tabular}{|l|l|l|}
\hline No & Bank & Inovasi Produk \\
\hline 1 & BII Syariah & $\begin{array}{l}\text { Tabungan Musafir Paltinum, Giro } \\
\text { paltinum, Deposito Platinum }\end{array}$ \\
\hline 2 & Danamon Syariah & Gadai Emas Syariah \\
\hline 3 & Bank Syariah Mandiri & Gadai Syariah \\
\hline 4 & BNI Syariah & $\begin{array}{l}\text { Gadai Emas, reksadan Syariah, Kartu } \\
\text { Kredit Syariah }\end{array}$ \\
\hline
\end{tabular}

\section{Metodologi}

Artikel ini bertujuan untuk menggambarkan berbagai macam tantangan yang dihadapi oleh industri perbankan syariah di Indonesia, dan bagaimana mengubah tantangan menjadi peluang bagi perkembangan industri perbankan syariah. Penelitian ini merupakan pengembangan model konseptual, dengan melakukan analisis terhadap berbagai macam tantangan yang dihadapi oleh perbankan syariah, dan berusahan mengubah tantangan tersebut menjadi peluang. Pemanfaatan ICT dalam pengembangan perbankan syariah dan membangun ketersediaan pendanaan akan membantu industri perbankan syariah agar berkembang. Penelitian ini merupakan studi dokumentasi, dan didasarkan pada data sekunder yang diperoleh dari jurnal, majalah dan internet.

\section{Hasil dan Pembahasan}


Tantangan Perbankan Syariah di Indonesia

Industri perbankan secara umum menghadapi berbagai tantangan, yaitu berkembangnya konglomerasi jasa keuangan, mulai berlakunya Masyarakat Ekonomi Asean (MEA), ketidakpastian perkonomian global, meningkatnya isu lingkungan hidup dan ketimpangan ekonomi pada skala global, pergantian kepemimpinan nasional, dan berakhirnya periode implementasi Arsitektur Perbankan Indonesia (API) tahun 2013 (Booklet Perbankan Indonesia 2016).

Persaingan dalam industi pasar keuangan, termasuk di dalamnya industri perbankan syariah terus meningkat setelah diberlakukanya MEA. Maka, tidak ada pilihan lain bagi industri perbankan syariah, kecuali harus terus ikut mengembangkan diri menuju industri perbankan yang unggul. Akan tetapi, dalam upaya pengembangan perbankan syariah, industri ini mengalami banyak tantangan, baik yang berasal dari internal maupun dari faktor eksternal.

Berbagai macam tantangan dihadapi oleh industri perbankan syariah, terlebih setelah pada tahun 2016 (sudah mulai diberlakukan MEA) yang secara langsung berdampak pada industri perbankan syariah, khususnya dengan adanya ASEAN Banking Integration Framework (ABIF). ABIF adalah inisiatif ASEAN yang bertujuan untuk menciptakan mekanisme integrasi dan mempercepat integrasi perbankan melalui pemberian akses pasar dan keluasan beroperasi di negara anggota ASEAN.

Industri perbankan syariah mengalamai berbagai macam tantangan yang segera harus diselesaikan agar perbankan syariah menjadi berkembang. Beberapa tantangan tersebut yaitu: Kapasitas SDM, sedikitnya jaringan kantor perbankan syariah di Indonesia, rendahnya pemahaman masyarakat terhadap konsep perbankan syariah, belum optimalnya sistem kelembagaan dan pelayanan perbankan syariah ( teermasuk produk perbankan syariah yang tidak beragam), dan sulitnya pengelolaan likuiditas dana (Booklet Perbankan Indonesia 2016).

Hal lain yang dapat mendorong perkembangan industri perbankan syariah di Indonesia adalah

\section{Peluang - Perkembangan industri perbankan syariah di Indonesia pada tahun 2016}

Walaupun pada tahun 2016 industri perbankan syariah mengalami perkembangan yang sedikit melambat dan mengalami penurunan share aset perbankan syariah terhadap aset perbankan nasional sebesar $4,67 \%$ dibandingkan tahun sebelumnya sebedar 4,9\% (Booklet Perbankan Indonesia 2016) perbankan syariah masih dapat survive dan berkembang. Ada beberapa peluang yang dapat dimanfaatkan oleh industri perbankan syariah agar industri ini tetap survive, sejajar bahkan mampu melampaui industri perbankan konvensional.

Pada tahun 2015 dan 2016 berbagai regulasi dikeluarkan oleh pemerintah

untuk merangsang pertumbuhan bisnis syariah. Selama tahun 2015, telah diterbitkan sebelas ketentuan perbankan syariah oleh OJK. Bahkan pada tahun 2016 Pemerintah telah membentuk Komite Nasional Keuangan Syariah (KNKS) untuk mendorong perkembangan industri ini.

Momentum yang seharusnya juga dapat mempercepat perkembangan industri keuangan syariah di Indonesia, adalah konversi beberapa Bank menjadi bank syariah, pada tahun 2016. Konversi Bank Pembangunan Daerah (BPD) Aceh menjadi bank syariah telah menambah aset industri perbankan syariah sebesar 20 Triliun. Momentum konversi ini yang kemudian akan segera ditambah dengan konversi dua bank dan Unit usaha syariah pada tahun 2017, akan semakin memperbesar market share industri perbankan syariah.

Momentum lain untuk perkembangan industri ini adalah rencana penambahan modal yang akan dilakukan oleh Bank Muamalat Indonesia. Penambahan modal seharusnya dapat diikuti oleh perbankan syariah yang lain, sebagai salah satu upaya dalam mengatasi permaslahan yang dihadapi perbankan syariah berkaitan dengan keterbatasan modal atau pendanaan.

dorongan dari OJK yang telah membuat roadmap perkembangan perbankan syariah, stimulus 
pengembangan produk dan edukasi perbankan syariah dengan agenda seminar tahunan yang dilakukan oleh OJK. Secara ringkas, tantangan yang dihadapi oleh perbankan syariah di
Indonesia, dan peluang yang dapat diambil oleh Perbankan syariah disajikan dalam tabel 2 sebagai berikut .

Tabel 2. Tantangan dan Peluang Perbankan Syariah di Indonesia

\begin{tabular}{|c|c|c|}
\hline No & Tantangan & Peluang \\
\hline 1 & $\begin{array}{l}\text { Sedikitnya jaringan kantor perbankan } \\
\text { syariah di Indonesia }\end{array}$ & 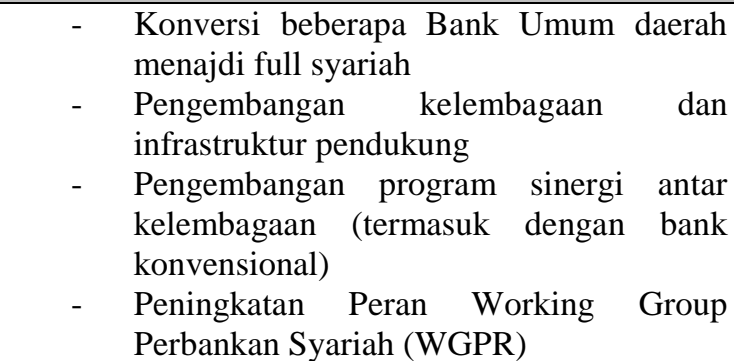 \\
\hline 2 & $\begin{array}{l}\text { Kuantitas dan Kualitas SDM yang } \\
\text { belum memadai }\end{array}$ & $\begin{array}{llll}\text { - } & \text { Demografi ekonomi : peningkatkan } \\
\text { ketersediaan SDM } & \\
\text { - } & \text { Edukasi dan komunikasi } & \end{array}$ \\
\hline 3 & $\begin{array}{l}\text { Rendahnya Pemahaman dan } \\
\text { kesadaran masyarakat terhadap } \\
\text { konsep syariah }\end{array}$ & $\begin{array}{llr}\text { - } & \text { Edukasi Perbankan Syariah yang } \\
\text { dilakukan oleh OJK } & \\
\text { - } & \begin{array}{l}\text { Inovasi Produk yang dapat merubah } \\
\text { oerilaku masyarakat sesuai konsep syariah } \\
\text { (dimensi sosial) }\end{array} \\
\end{array}$ \\
\hline 4 & $\begin{array}{l}\text { Belum optimalnya sistem } \\
\text { kelembagaan perbankan syariah }\end{array}$ & $\begin{array}{l}\text { - Dorongan OJK terhadap kualitas good } \\
\text { governance }\end{array}$ \\
\hline 5 & $\begin{array}{l}\text { Belum optimalnya pelayanan } \\
\text { perbankan syariah }\end{array}$ & $\begin{array}{ll}\text { - } & \begin{array}{l}\text { Kebijakan kualitas layanan perbankan } \\
\text { syariah }\end{array} \\
\text { - } & \text { Peningkatan Service Excellene } \\
\end{array}$ \\
\hline 6 & Produk yang tidak variatif & $\begin{array}{ll}\text { - } & \text { Kebijakan pengembangan perbankan } \\
\text { syariah tentang inovasi produk perbankan } \\
\text { ssyariah } \\
\text { - } \quad \begin{array}{l}\text { Kustomisasi produk sesuai preferensi } \\
\text { masyarakat sejalan dengan prinsip syariah }\end{array} \\
\text { - } & \text { Inovasi Produk berbasis ICT }\end{array}$ \\
\hline 7 & Modal yang belum memadai & 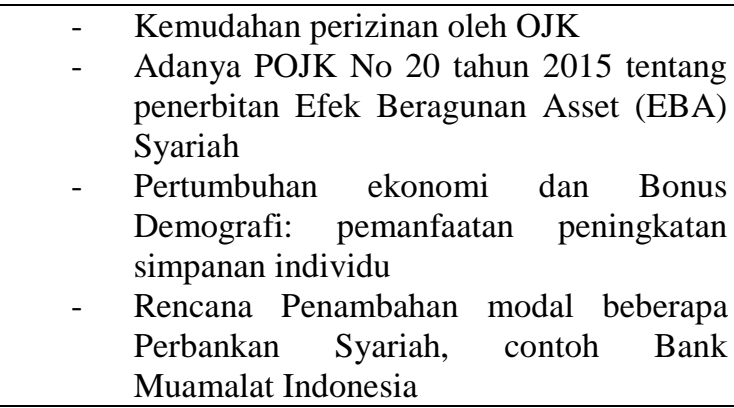 \\
\hline
\end{tabular}

Sumber : Roadmap Perbankan Syariah Indonesia, diolah, 2016

Arah- Strategi : Model Pengembangan Perbankan syariah

Arah pengembangan Perbankan Nasional sesuai OJK bersifat komprehensif dan terintegrasi dengan penyusunan arah pengembagnan pasar modal dan industri keuangan non Bank. Arah pengembangan perbankan syariah dalam jangka menengah adalah pengembangan produk dan layanan yang berkualitas, inovatif, berbeda, dan lebih unggul (distinct) dari produk perbankan konvensional, dan perluasan jaringan yang luas agar mampu memenuhi kebutuhan masyarakat akan jasa keuangan syariah (Booklet Perbankan Inonesia 2016). 
Berdasarkan Roadmap Perbankan Syariah Indonesia 2015 - 2019, visi pengembangan perbankan syariah nasional adalah Mewujudkan perbankan syariah yang berkonribusi signifikan bagi pertumbuhan ekonomi berkelanjutan, pemerataan pembangunan, dan stabilitas sistem keuangan serta berdaya saing tinggi. Visi ini, merupakan pengembangan dari kebijakan pengembangan perbankan syariah pada tahuntahun sebelumnya yang memfokuskan diri pada: penguatan intermediasi perbankan syariah pada sektor ekonomi produktif, pengembangan dan pengayaan produk perbankan syariah yang lebih terarah, peningkatan sinergi dengan bank induk, peningkatan edukasi dan komunikasi (fokus pada parity dan distinctiveness), dan peningkatan good governance dan pengelolaan resiko kegiatan usaha perbankan syariah dan penguatan sistem pengawasan. Arah kebijakan pengembangan perbankan syariah di Indonesia dijelaskan dalam tabel 3.

Tabel 3. Arah kebijakan Perbankan Syariah di Inonesia 2015 - 2019

\begin{tabular}{|l|l|}
\hline No & Arah Kebijakan Pengembangan Perbankan Syariah \\
\hline 1 & Memperkuat sinergi Kebijakan antara otoritas dengan pemerintah dan stakeholder \\
\hline 2 & $\begin{array}{l}\text { Memperkuat permodalan dan skala usaha serta memperbaiki efisiensi, dengan } \\
\text { program kerjanya }\end{array}$ \\
\hline 3 & Memperbaiki kualitas layanan dan keragaman produk \\
\hline 4 & Memperbaiki kulitas SDM dan TI dan infrastruktur lainya \\
\hline 5 & Meningkakan literasi dan preferensi masyarakat \\
\hline 7 & Memperkuat harmonisasi pengaturan dan pengawasan \\
\hline
\end{tabular}

Sumber : data Roadmap Perbankan Syariah Nasional di olah, 2016

Berdasarkan analisis terhadap tantangan yang akan dihadapi oleh perbankan syariah, dan berbagai macam peluang yang ada, serta dengan berpedoman pada arah kebijakan pengembangan perbankan syariah di Indonesia oleh Bank Indonesia, maka strategi utama yang dapat dilakukan oleh Perbankan syariah di Indonesia adalah sebagai berikut:

\section{Upaya Menjawab berbagai Tantangan yang dihadapi oleh Perbankan Syariah}

Salah satu tantangan yang harus segera dijawab oleh perbankan syariah adalah terkait belum optimalnya pelayanan perbankan syariah terutama penyediaan produk perbankan syariah, yaitu dengan melakukan inovasi produk perbankan syariah. Inovasi produk perbankan syariah adalah syarat mengikuti trend agar perbankan syariah menjadi industri yang kuat dan menjadi pilihan bagi masyarakat. Perbankan syariah harus melakukan inovasi produk dengan memanfaatkan peluang pemanfaatan ICT, dengan memyediakan produk yang beragam agar berkembang dengan baik. Inovasi produk perbankan syariah adalah sebuah upaya yang harus dilakukan, agar perbankan syariah dapat tumbuh dan bersaing dengan perbankan konvensional maupun lembaga keuangan lainnya.

Terlebih, jika dilihat dari aspek kontribusi terhadap perekonomian Indonesia, penggunaan berbagai produk dan instrumen keuangan syariah (baca: inovasi produk) akan sangat bermanfaat. Penggunaan produk keuangan syariah yang lebih dekat dengan sektor riil, akan menciptakan hubungan yang baik antara sektor keuangan dengan sektor riil. Dengan semakin banyaknya penggunaan produk dan instrumen keuangan syariah, maka transaksi-transaksi yang bersifat spekulatif akan berkurang sehingga memperkuat stabilitas sistem keuangan secara keseluruhan. Hal ini tentu saja akan menciptakan kestabilan harga jangka menengah dan jangka panjang, sehingga kegiatan keuangan bejalan secara sehat, menciptakan iklim usaha yang sehat, dan pada akhirnya bisnis msyarakat juga akan berkembang. 
Inovasi produk perbankan syariah yang harus dilakukan oleh industri perbankan syariah ini sesuai dengan arah kebijakan yang telah ditetepkan oleh Bank Indonesia. Dalam melakukan inovasi produk, industri perbankan syariah harus cerdas memanfaatkan peluang perkembangan teknologi dengan penyediaan produk berbasis ICT, sehingga lebih diminati masyarakat. Inovasi produk yang dilakukan perbankan syariah seharusnya memperhatikan dimensi ekonomi dan sosial (MS, 2015). Dari aspek ekonomi, maka inovasi produk perbankan syariah yang dilakukan untuk pengembangan produk harus sejalan dengan kebutuhan dari nasabah, tetapi dengan tetap mematuhi aturan syariah (syariah compliance). Dengan demikian, inovasi produk dapat melahirkan produk bank yang variatif (Henni, 2011). Sebagai industri perbankan syariah yang dilandasi oleh nilai-nilai islami, maka perbankan syariah memiliki peran strategis dari aspek sosial, yaitu dengan melakukan pendidikan kepada masyarakat, melalui inovasi produk yang dapat “mensyariatkan" perilaku masyarakat (MS, 2015)

Dari uraian di atas, maka untuk menjawab berbagai tantangan yang dihadapi, pengembangan perbankan syariah nasional harus dilakukan dengan sinergi antara OJK sebagai otoritas keuangan sebagai penentu arah kebijakan, Perbankan syariah sebagai pelaku bisnis, dan masyarakaat sebagai nasabah yang menggunakan produk perbankan syariah dengan memanfaatkan berbagai peluang yang ada.

Gambar 1

Model pengembangan industri perbankan syariah (dengan pemanfaatan ICT dan kecukupan pendanaan)
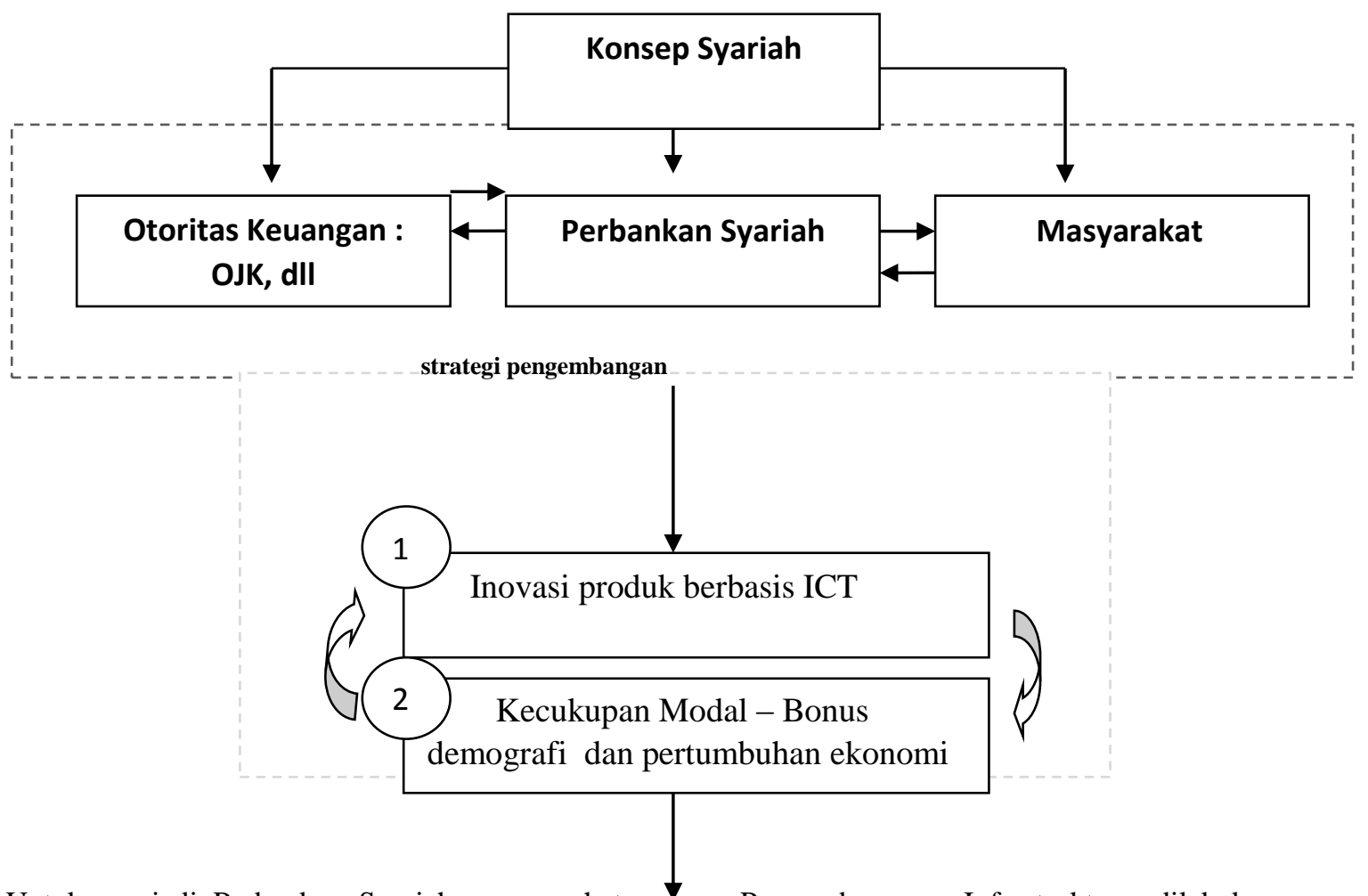

Untuk menjadi Perbankan Sya pranfrastruktur dilakukan agar kontributif, berdaya saing, $m$ Perbankan Syariah yang Sehat, perbagai layanan informasi, dalam Qualified Asean bank kontributif, dan berdaya saing masuk mputasi dapat dilakukan. sinergi antara otoritas jasa keu dalam QAB (Qualified Asean Bank) syariah, dan masyarakat dengan memanfaatkan Pemanfaatan ICT dalam perbankan syariah ICT dalam inovasi produk, dan berupaya memenuhi kecukupan modal, agar proses inovasi produk dapat terpenuhi. Karena dibutuhkan sarana penunjang, berupa pengembangan infrastruktur yang memadai dalam rangka inovasi produk berbasis ICT. Sebaliknya, inovasi produk berbasis ICT akan membantu perbankan syariah untuk memenuhi likuitas dana dengan penyediaan produk variatif sesuai preferensi masyarakat. Industri Perbankan Syariah seharusnya mampu mengubah tantangan menjadi peluang dengan memanfaatkan ICT untuk meningkatkan daya saing dengan perbankan konvensional. Dalam konteks tantangan dan peluang bisnis pada bidang perbankan syariah, pemanfaatan ICT dalam industri perbankan syariah masih rendah, sehingga industri perbankan syariah harus terus didorong untuk meningkatkan pemanfaatan ICT 
baik dalam tata kelola (good governance), sesuai dengan arah kebijakan pengembangan perbankan syariah Bank Indonesia, maupun inovasi produk perbankan syariah. Dalam upaya peningkatan good governance, perbankan syariah harus memanfaatkan ICT untuk membangun sistem informasi perbankan syariah yang dapat mempermudah semua proses transaksi yang ada, sekaligus memungkinkan inovasi produk baru perbankan syariah. Inovasi produk perbankan syariah berbasis ICT harus didukung oleh Sistem informasi yang memadai (sistem informasi berbasis ICT).

\section{Pemanfaatan ICT dalam inovasi produk perbankan syariah}

Inovasi produk perbankan syariah merupakan pilar utama dalam pengembangan perbankan syariah. Dalam melakukan inovasi produk, perbankan syrariah harus memperhatikan berbagai pertimbangan. Inovasi produk perbankan syariah sudah seharusnya memanfaatkan ICT agar produk perbankan syariah memiliki daya saing dengan produk perbankan konvensional. Berbagai inovasi produk dengan pemanfaatan ICT pada perbankan yang telah dikenal oleh masyarakat adalah ATM, Phone Banking, Debet card, EFT pos, Cash Management, Corporate Intenet banking, Individual internet service.

Peluang inovasi produk berbasis ICT yang seharusnya dapat dikembangkan oleh perbankan syariah di Indonesia seperti international trade finance, sindicated financing, Margin During Construction (MDC), hybrid take over dan refinancing, factoring, KPRS inden, pembiayaan reimburs, IMBT dan Ijarah Maushifah fiz Zimmah, serta Musyarakah Mutanaqishah..

\section{KESIMPULAN DAN SARAN}

Industri perbankan syariah di Indonesia harus terus dikembangkan. Pengembangan Perbankan syariah Nasional perlu didorong oleh semua pihak yang terkait, baik otoritas keuangan, masyarakat, maupun akademisi. Pengembangan perbankan syariah seharusnya sejalan dengan arah kebijakan perbankan syariah nasional sesuai dengan yang dirumuskan dalam Roadmap Perbankan Syariah nasional oleh Otoritas Jasa Keuangan. Pmemanfaatkan teknologi informasi dan kecukupan pendanaan akan membantu industri perbankan syariah berkembang, survive, menjadi perbankan yang sehat, dan berkontribusi bagi perkonomian nasional..

Salah satu pemanfaatan teknologi informasi dan komunikasi dalam perbankan syariah untuk menjawab tantangan yang dihadapi oleh perbankan syariah adalah inovasi produk berbasis
ICT. Inovasi produk berbasis ICT dapat menjadi sebuah solusi yang dapat diterapkan untuk mengembangkan industri perbankan syariah di Indonesia. Selain inovasi produk berbasis ICT, perbankan syariah harus berupaya meningkatkan kecukupan modal dengan memanfaatkan peluang pertumbuhan ekonomi, dan bonus demografi dengan melakukan usaha-usaha yang sesuai dengan nilai-nilai Islam untuk mengatasi salah satu masalah klasik perbankan syariah di Indonesia yaitu kesulitan likuiditas dana. Dengan melakukan inovasi produk, dan meningkatkan kecukupan modal, maka perbankan syariah Nasional dapat menjadi perbankan yang sehat, kontributif, dan berdaya saing tinggi.

\section{Daftar Pustaka}

Alamsyah, H. (2010). Perkembangan dan Prospek Perbankan Syariah Indonesia.

Andriansyah, Y. (2009). Kinerja Keuangna Perbankan Syariah di Indonesia dan Kontribusinya terhadap Pembangunan Nasional. Jurnal Ekonomi Islam , La riba.

Fitri, A. (2010). Beberapa Permasalahan Perbankan Syariah di Indonesia.

Henni, I. (2011). Analisis Faktor-Faktor Yang Mempengaruhi Inovasi Produk Perbankan Syariah di Indonesia.

Himatansi. (2009). Metode dan PilarInovasi Produk Bank Syariah.

Keuangan, O. J. (2016). Booklet Perbankan Indonesia .

Keuangan, O. j. (2016). Roadmap Perbankan Syariah Indonesia 2015-2019.

Masulah. (2013). Strategi Pengembangan Perbankan Syariah di Indonesia.

MS, A. M. (2015). Keterlekatan Sosial Inovasi Produk Bank Syariah di Indonesia. Jurnal Hukum Islam.

Rifai, H. A. (2009). Identifikasi faktor Penentu Keputusan Konsumen Dalam memilih jasa Perbankan. 